Металлофиз. новейшие технол. / Metallofiz. Noveishie Tekhnol. () 2014 ИМФ (Институт металлофизики 2014 , т. 36, № 12, сс. 1597-1608

Оттиски доступны непосредственно от издателя

им. Г. В. Курдюмова НАН Украины)

Фотокопирование разрешено только

Напечатано в Украине.

в соответствии с лицензией

PACSnumbers: 61.66.Dk, 61.72.Ff, 61.72.Qq, 62.20.Qp, 81.05.Bx, 81.10.Fq, 81.30.Mh

\title{
Structural Characterization and Precipitation in AlMg5Si2Mn Alloy
}

\author{
V. V. Boyko, T. Link, and K. V. Mykhalenkov* \\ Technical University Berlin, \\ Institute for Materials Science and Technology, \\ Sekr.BH 18, Ernst-Reuter-Platz 1, \\ D-10587 Berlin, Germany \\ "National Technical University of Ukraine 'Kyiv Polytechnic Institute', \\ Politekhnichna Str. 35, Bldg. 9, Room 610, \\ 03056 Kyiv, Ukraine
}

The as-cast structure of permanent mould and high-pressure die-castings of the AlMg5Si2Mn alloy is investigated by differential scanning calorimetry, microhardness measurements, transmission electron microscopy, and energy dispersive $\mathrm{X}$-ray analysis. Inside the $\alpha$-Al grains, the curved plate-like precipitates are detected for both alloys. Examination of these precipitates reveals a number of features, such as follow: (i) the composition of the precipitates is very close to the stoichiometric $\mathrm{Mg}_{2} \mathrm{Si}$ compound; (ii) precipitates are aligned along dislocations; (iii) the precipitate density is much higher for the highpressure die-castings, where the $\alpha$-Al matrix contains more dislocations than in permanent mould castings; (vi) precipitates lie inside the $\alpha$-Al grains, where they are randomly distributed. Precipitates are not observed among the $\mathrm{Mg}_{2} \mathrm{Si}$ lamellas. Most likely, these precipitates are $\beta^{\prime \prime}$-phase, and the mechanism of their formation is the heterogeneous nucleation on dislocations.

В роботі представлено результати дослідження структури стопу AlMg5Si2Mn, одержаного виливанням у кокіль та під тиском. За допомогою диференційної сканівної калориметрії, вимірів мікротвердости, трансмісійної електронної мікроскопії і локальної рентгеноспектральної аналізи було встановлено, що всередині зерен $\alpha$-Al в литому стані спостерігаються вигнуті пластинчасті виділення. Дослідженнями цих виділень було встановлено, що: їх склад близький до стехіометричного складу $\mathrm{Mg}_{2} \mathrm{Si}$; виділення однією стороною приєднані до дислокацій; кількість виділень значно більша в стопі, відлитому під тиском, ніж у випадку кокільного виливання; виділення розміщуються тільки в зернах твердого розчину, а між лямелями евтектики не спостерігаються. Найбільш вірогідно, що такі виділення $\epsilon$ частинками $\beta$ "-фази, і головним механізмом їх утворення $\mathrm{e}$ гетерогенне зародження на дислокаціях. 
В работе представлены результаты исследования структуры сплава AlMg5Si2Mn, полученного литьём в кокиль и под давлением. С использованием дифференциальной сканирующей калориметрии, измерений микротвёрдости, трансмиссионной электронной микроскопии и локального рентгеноспектрального анализа установлено, что внутри зёрен $\alpha-\mathrm{Al}$ в литом состоянии наблюдаются выгнутые пластинчатые выделения. Исследования таких выделений показали, что: их состав близок к стехиометрическому составу $\mathrm{Mg}_{2} \mathrm{Si}$; выделения одной стороной соприкасаются с дислокациями; количество выделений значительно выше в сплаве, отлитом под давлением, чем в случае кокильного литья; выделения располагаются только в зёрнах твёрдого раствора, а между ламелями эвтектики не обнаруживаются. Наиболее вероятно, что такие выделения являются частицами $\beta^{\prime \prime}$-фазы, и основным механизмом их образования является гетерогенное зарождение на дислокациях.

Key words: precipitates, element distribution, natural hardening, aluminium casting alloy.

(Received May 25, 2014)

\section{INTRODUCTION}

Design of new lightweight alloys for gradual replacement of iron and steel parts is now the mainstream in energy saving and improvement of fuel efficiency in the transportation sector. Parallel to the powerful advances in aluminium wrought alloys, search for novel highperformance casting alloys still attracts attention of both researchers and manufacturers of aluminium casting. The last decades showed growing interest in $\mathrm{Al}-\mathrm{Mg}-\mathrm{Si}-\mathrm{Mn}$ casting alloys, which are considered as potential competitors for established commercial materials. Despite of active implementation of $\mathrm{Al}-\mathrm{Mg}-\mathrm{Si}-\mathrm{Mn}$ alloys into foundry practice [1, 2], structure formation and microstructural reasons for their outstanding mechanical properties are not fully understood. Being long time in the shadow, alloys of the system $\mathrm{Al}-\mathrm{Mg}-\mathrm{Si}-\mathrm{Mn}$ returned into the market in 1996 [1-5]. It was reported by Koch et al. [2] that a Al-alloy with the nominal composition AlMg5Si2Mn subjected to high-pressure die-casting shows one of the best properties regarding ductility (up to $18 \%$ ), yield strength (up to $220 \mathrm{MPa}$ ), and ultimate tensile strength (up to $350 \mathrm{MPa}$ ) compared with other casting alloys.

Comparing AlSi7Mg and AlMg5Si2Mn casting alloys, the most evident difference is that the highest strength for AlSi7Mg is achieved only after heat treatment, whereas AlMg5Si2Mn exhibits its highest properties in as-cast condition. It was reported recently by Wang [6] that A356 (AlSi7Mg) casting alloy can be artificially aged without solution treatment and that such aging results in the formation of $\beta^{\prime}$-precipitates acting as strengthening phase. However, for the AlMg5Si2Mn alloy, the 
reasons for its good mechanical properties are still under discussion.

In this article, the as-cast condition of the AlMg5Si2Mn alloy after permanent mould casting and high-pressure die-casting is characterized comprehensively regarding structure, elements distribution, and precipitates.

\section{EXPERIMENTAL PROCEDURE}

Two $\mathrm{Al}-\mathrm{Mg}-\mathrm{Si}-\mathrm{Mn}$-type alloys are subject of the research program. Their chemical compositions are presented in Table 1. The first one (alloy number 1) is prepared using a resistance furnace and graphite crucible (batch weight of $0.25 \mathrm{~kg})$. The starting materials are $\mathrm{Al}(99.9 \%$ purity), $\mathrm{Mg}$ (99.9\% purity), and AlSi25 and AlMn26 master alloys. Prior to casting, the melt is treated by argon blowing for $10 \mathrm{~min}$. After blowing the melt surface is skimmed to remove dross. Sample 1 was cast into a permanent mould (PM). Casting temperature of $710^{\circ} \mathrm{C}$ and mould temperature of $22^{\circ} \mathrm{C}$ lead to a cooling rate of $5 \mathrm{~K} \cdot \mathrm{s}^{-1}$.

Sample 2 is commercial alloy produced by high-pressure die-casting (HPDC) in form of a $3 \mathrm{~mm}$ thick plate thus the impurities content (Fe, $\mathrm{Ti}, \mathrm{Zn}, \mathrm{Cu}$ ) in it is higher than that of melted in laboratory (sample 1).

Sample 3 is the commercial A356 casting alloy, which is included for comparison. Initial materials, melting technique and casting conditions are kept the same for all alloys.

Differential scanning calorimetry (DSC) measurements are performed using a NETZSCH DSC 404 instrument. During DSC measurements, specimens are protected under an argon atmosphere with a flow rate of $75 \mathrm{ml} \cdot \mathrm{min}^{-1}$. The measurements are performed in the temperature range 20 to $700^{\circ} \mathrm{C}$ at a heating rate $10^{\circ} \mathrm{C} \cdot \mathrm{min}^{-1}$.

Samples for microstructure observations in light microscope (LM) are prepared using conventional metallographic techniques. Transmission electron microscopy (TEM) observations are carried out on thin foils cut from bulk samples. Disks with diameter $3 \mathrm{~mm}$ and thickness of $150 \mu \mathrm{m}$ were electropolished with a twin jet STRUERS Tenupol 3, using $70 \%$ methanol, $20 \%$ glycerol, and $10 \%$ perchloric acid electrolyte kept at $-27^{\circ} \mathrm{C}$ and a tension of $20 \mathrm{~V}$. Specimens were investigated in a PHILIPS CM-30 TEM operated at $300 \mathrm{kV}$ accelerating voltage and

TABLE 1. Chemical composition of alloys under investigation.

\begin{tabular}{c|c|c|c|c|c|c|c|c}
\hline \multirow{2}{*}{ Sample } & \multicolumn{7}{|c}{ Elements content, wt.\% (Al-balance) } \\
\cline { 2 - 9 } & $\mathrm{Mg}$ & $\mathrm{Si}$ & $\mathrm{Mn}$ & $\mathrm{Cu}$ & $\mathrm{Zn}$ & $\mathrm{Ti}$ & $\mathrm{Be}$ & $\mathrm{Fe}$ \\
\hline 1 & 5.32 & 2.12 & 0.58 & 0.001 & 0.001 & 0.02 & - & 0.03 \\
2 & 5.47 & 2.20 & 0.69 & 0.02 & 0.01 & 0.1 & 0.004 & 0.12 \\
3 & 0.32 & 6.97 & 0.02 & - & - & 0.01 & - & 0.06 \\
\hline
\end{tabular}


equipped with a Noran System Six EDS system from Thermo Scientific. Element concentrations are measured using spot size of 4-8 nm. These concentrations are averaged over measurements in 10 individual grains (for sample 2) or dendrite arms (for samples 1 and 3).

Hardness measurements are performed using Brinell hardness testing machine with ball diameter of $2.5 \mathrm{~mm}$ and load $62.5 \mathrm{~kg}$. Microhardness tests are carried out on polished non-etched specimens on a Duramin-2 microhardness tester. These Vickers microhardness measurements are performed on primary $\alpha$-Al grains (sample 2) or dendrite arms (samples 1 and 3 ) using $0.05 \mathrm{Kgf}$ load for 10 seconds.

\section{RESULTS}

\subsection{Differential Scanning Calorimetry}

In a DSC experiment, the specimen under investigation and a reference specimen are heated up and cooled down simultaneously. The reference specimen must not show any phase transition in the investigated temperature range. The difference in energy consumption or production per time and mass between specimen and reference is measured during such a heating cycle. This so-called heat flow is plotted as a function of temperature. A positive peak indicates an exothermic reaction, namely, solidification or precipitation. A negative peak stands for an endothermic reaction, i.e. melting or dissolution.

The DSC plots obtained from the as-cast samples during heating are shown in Fig. 1. In sample 3, three peaks can be distinguished, denoted as heat effect 1, 2, 3. Their characteristic temperatures at start ('peak onset'), extremum ('peak'), and end ('peak offset') are summarized in Table 2. Sample 2 shows the same strong peaks 2 and 3 as sample 1 , but not the small peak 1.

This first thermal reaction during heating is an exothermic effect with peak onset at $220.0^{\circ} \mathrm{C}$ and peak temperature of $247.8^{\circ} \mathrm{C}$. The next thermal reaction is observed at a peak onset temperature of $596.2^{\circ} \mathrm{C}$ for sample 1 and $574.4^{\circ} \mathrm{C}$ for sample 3 . This endothermic effect is attributed to the melting of $(\mathrm{Al})+\left(\mathrm{Mg}_{2} \mathrm{Si}\right)$ and $(\mathrm{Al})+(\mathrm{Si})$ eutectics, respectively. Further heating resulted in appearance of the endothermic peak with onset $618.0^{\circ} \mathrm{C}$ for sample 1 and $608.7^{\circ} \mathrm{C}$ for sample 3 . This effect is related to the melting of $\alpha-\mathrm{Al}$ (Fig. 1, $b$ ).

\subsection{Microstructure Observations}

In this section, the microstructural features are presented with increasing magnification starting at the scale of the microstructure. Figure 2 represents the as polished microstructure of samples 1 and 2 . 


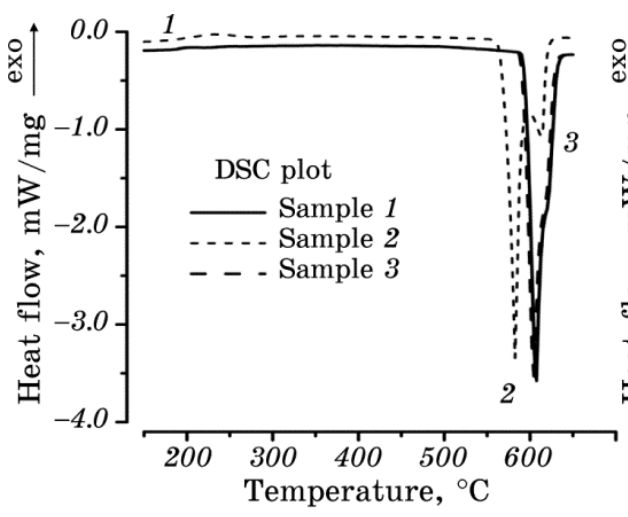

$a$

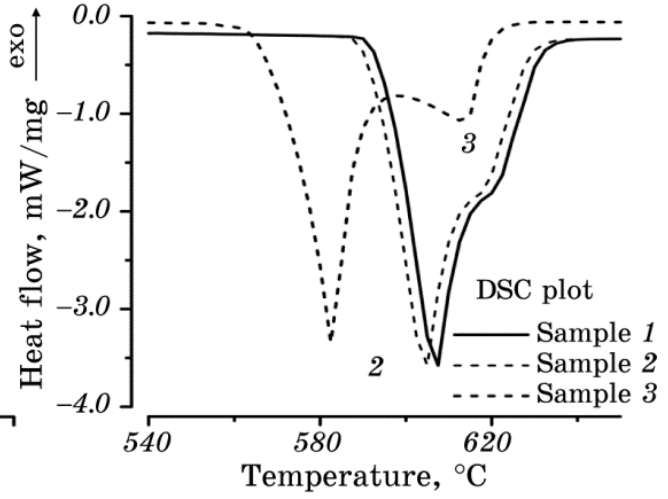

$b$

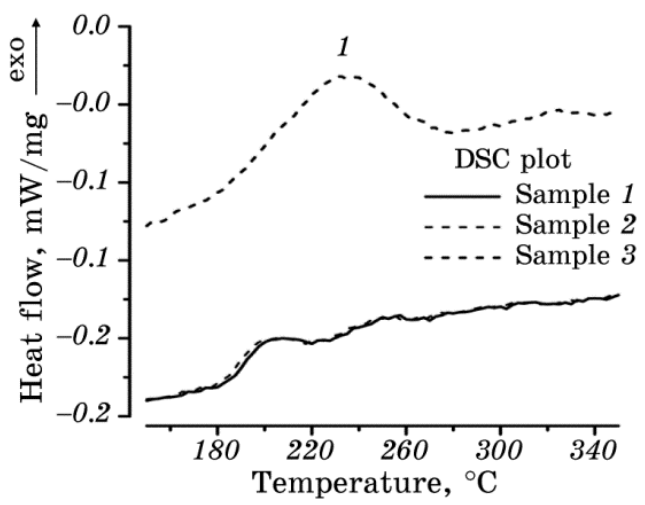

$c$

Fig. 1. The DSC traces for samples 1,2 , and 3 at a heating rate $10 \mathrm{~K} \cdot \mathrm{s}^{-1}$. The DSC plot over the full temperature range. Heat effects marked as $1-3(a)$. Spread endothermic heat effects 2 and $3(b)$. Spread exothermic heat effect 1 , visible only in sample $3(c)$.

The microstructure of both samples consists of primary $\alpha$-Al grains (light areas) and (Al) $+\left(\mathrm{Mg}_{2} \mathrm{Si}\right)$ eutectic (grey). Sample 1 exhibits a dendritic morphology of $\alpha$-Al grains surrounded by eutectic colonies. For sample 2, equiaxed globular-rosette morphology is preferential. More details of the microstructure of sample 2 can be seen in the TEM image (Fig. 5, $b$ ). The structure of AlSi7Mg casting alloy is well known [7] and will not be repeated here.

\subsection{Elements' Distribution}

$\alpha$-Al grain. In spite of the morphological difference caused by increased cooling rate and pressure effect for sample 2 , the composition 
TABLE 2. Characteristic temperatures of heat effects observed during heating of samples 1 and 3 .

\begin{tabular}{|c|c|c|}
\hline Peak & Sample 1 & Sample 3 \\
\hline \multicolumn{3}{|c|}{ Heat effect $1,{ }^{\circ} \mathrm{C}$ (exothermic) } \\
\hline Peak onset & - & 220,0 \\
\hline Peak & - & 247,8 \\
\hline Peak outset & - & 262,1 \\
\hline \multicolumn{3}{|c|}{ Heat effect $2,{ }^{\circ} \mathrm{C}$ (endothermic) } \\
\hline Peak onset & 596,2 & 574,4 \\
\hline Peak & 609,0 & 591,0 \\
\hline Peak outset & 618,0 & 608,7 \\
\hline \multicolumn{3}{|c|}{ Heat effect $3,{ }^{\circ} \mathrm{C}$ (endothermic) } \\
\hline Peak onset & 618,0 & 608,7 \\
\hline Peak & 624,3 & 619,1 \\
\hline Peak outset & 632,4 & 625,1 \\
\hline
\end{tabular}

of the matrix of sample 1 and 2 varies only slightly. The average $\mathrm{Mg}$ content in the $\alpha$-Al solid solution of sample 2 is $2.2 \pm 0.4$ wt.\% (Fig. 3), whereas for sample 1 it is $2.0 \pm 0.3 \mathrm{wt}$. \%. In some cases, high $\mathrm{Mg}$ concentrations up to 3.3-3.8 wt.\% were found in both specimens. Measurement of the $\mathrm{Mg}$ distribution across the $\alpha$-Al grain in sample 2 (Fig. 3, b) and dendrite arms in sample 1 showed a lower Mg concentration in the centre of the grain or the dendrite arm compared with the eutectic surrounding.

For both samples, the $\mathrm{Mn}$ content in $\alpha$-Al solid solution was $0.3-0.4$ $\pm 0.05 \mathrm{wt} . \%$, and no Mn-containing precipitates or separate phases were observed. In the HPDC alloy (sample 2), the Ti concentration of 0.07 wt. $\%$ is close to the detection limit. Its distribution seems to be inhomogeneous and reaches in some point of 0.33 wt.\%. The Si concentration in the $\alpha$-Al grains of sample 1 and 2 was less than 0.1 wt. $\%$. The EDX measurements in sample 3 showed a higher Si concentration in the $\alpha$-Al grain of about $0.9-1.2 \mathrm{wt} . \%$ and for $\mathrm{Mg}$ of about $0.17-0.27$ wt. $\%$. The average composition of $\alpha-\mathrm{Al}$ matrix for all samples is represented in Table 3.

Eutectic. Sample 1 and 2 represent different morphologies of the (Al) + $\left(\mathrm{Mg}_{2} \mathrm{Si}\right)$ eutectic hereby indicating that the formation of eutectic in $\mathrm{Al}-$ $\mathrm{Mg}-\mathrm{Si}$ system is sensitive to the cooling rate. Eutectic in sample 1 is needle shaped (Fig. 2, a), and the thickness of the $\mathrm{Mg}_{2} \mathrm{Si}$ lamellas is about $1 \mu \mathrm{m}$. In sample 2 , the eutectic is short and fibrous (Fig. 2, b), and the average lamella thickness is about 70-110 nm. The EDX spec- 


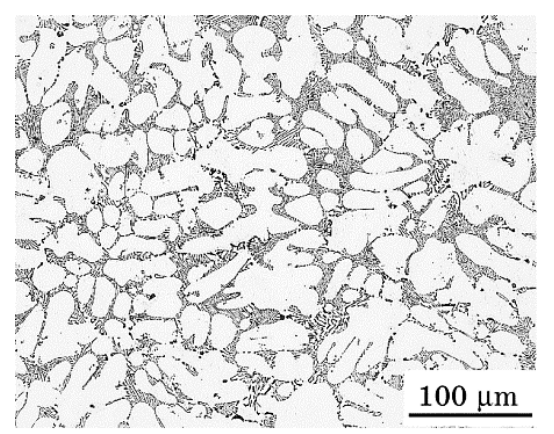

$a$

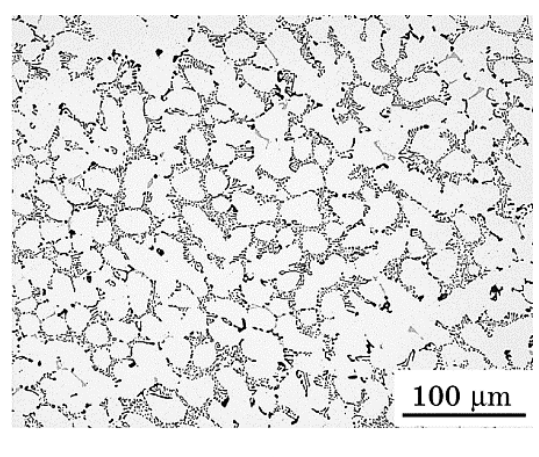

$b$

Fig. 2. Microstructure of samples $1(a)$ and $2(b)$. As-cast microstructure of sample 1 (permanent mould casting) (a). As-cast microstructure of sample 2 (high-pressure die-casting) (b).

tra of the lamellas showed high oxygen peaks. This oxygen contamination originates from the electrolytic preparation of foils. During electrolytic thinning of $\mathrm{Al}-\mathrm{Mg}-\mathrm{Si}$ alloys, they react with perchloric acid as follows: $\mathrm{Mg}_{2} \mathrm{Si}+4 \mathrm{HClO}_{4}=2 \mathrm{Mg}\left(\mathrm{ClO}_{4}\right)_{2}+2 \mathrm{SiH}_{4}$. Small amounts of $\mathrm{O}_{2}$ can cause further oxidation of silane $\mathrm{SiH}_{4}: \mathrm{SiH}_{4}+3 \mathrm{O}_{2}=\mathrm{SiO}_{2}+2 \mathrm{H}_{2} \mathrm{O}$. $\mathrm{SiO}_{2}$ remains in the foil, whereas $\mathrm{Mg}\left(\mathrm{ClO}_{4}\right)$ can dissolve in the electrolyte. Thus, the measured composition is totally changed. In thick areas of the TEM foil, however, the lamellas were covered by thin protective layer of aluminium. Measuring here and excluding the $\mathrm{Al}$ from quantification gave a composition of the eutectic lamella, very close to the stoichiometry of $\mathrm{Mg}_{2} \mathrm{Si}$, namely, $\mathrm{Mg} 62.5$ at. \% and $\mathrm{Si} 31.2$ at. $\%$.

Fe-containing phase. Inside the eutectic colonies in sample 2, blocky particles are observed (Fig. 4). Their average size is about 1.5 to 2.5 $\mu \mathrm{m}$. The EDX measurements performed on 15 separate particles

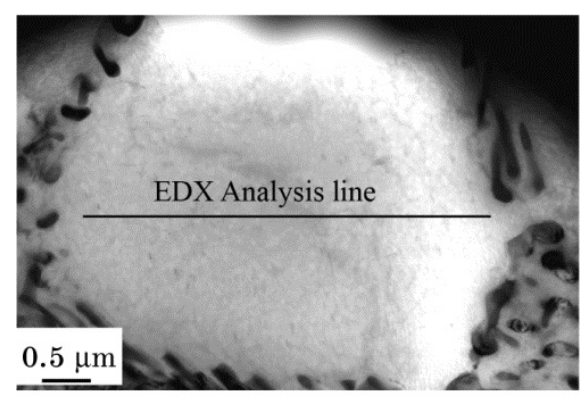

$a$

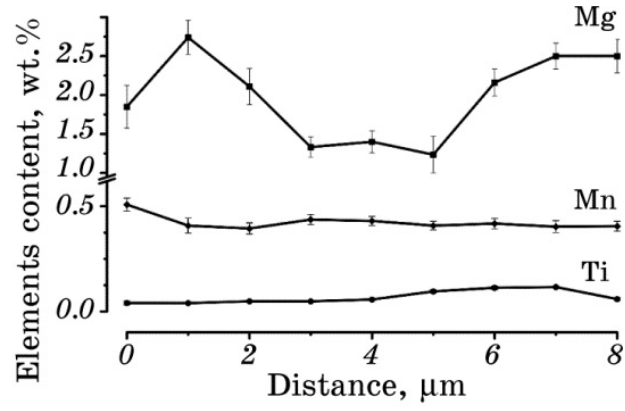

$b$

Fig. 3. Bright field image of separate grain in sample $2(a)$ and distribution of $\mathrm{Mg}, \mathrm{Mn}$ and Ti across the grain (b). 


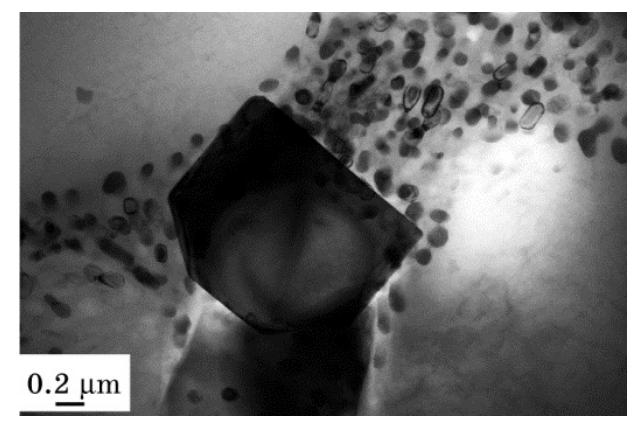

Fig. 4. Bright field image of blocky Fe-containing phase in sample 2 .

showed that this phase is enriched with $\mathrm{Fe}, \mathrm{Mn}$, and Si. The average composition of this phase is $6.7-7.0 \mathrm{wt} . \% \mathrm{Fe}, 18.0-23.0 \mathrm{wt} . \% \mathrm{Mn}$, 2.8-5.1 wt.\% Si, 0.0-1.1 wt.\% Mg (Al-rest). Measurements avoiding an overlap with matrix and eutectic material give: $\mathrm{Fe}-4.8$ at. $\%$, $\mathrm{Mn}-13.8$ at.\%, $\mathrm{Si}-3.3$ at. $\%$. On this basis, the Fe containing phase can be identified as $\alpha-\mathrm{Al}_{15}(\mathrm{FeMn})_{3} \mathrm{Si}$ phase. For samples 1 and 3 prepared on a laboratory scale using pure $\mathrm{Al}$ and $\mathrm{Mg}$, no Fe-containing phase is detected.

Precipitates. The most interesting results were obtained by TEM investigations of the $\alpha$-Al grains in samples 1 and 2, as shown in Fig. 5 . The solid solution grains contain plate-like particles, which can be recognized best in Fig. 5, $a$. Here, one sees more than 10 plates, elongated and aligned in horizontal direction. On their right side, they are connected by a curved line, which could be identified as a dislocation. On the left side of the micrograph, one can see a vertical slightly curved line, which is such a dislocation. In this case, the plates protrude into the image plane and therefore one has free sight on the bounding dislocation.

The exact chemical composition of the precipitates in samples 1 or 2 could not be measured, because the plates are so thin, that the surrounding matrix material contributes much more to the EDX spectrum than the precipitate. Anyhow, spectra collected from such areas

TABLE 3. Average elements concentrations in $\alpha$-Al solid solution measured for samples $1-3$.

\begin{tabular}{c|c|c|c|c}
\hline \multirow{2}{*}{ Sample } & \multicolumn{4}{|c}{ Elements content, wt.\% } \\
\cline { 2 - 5 } & $\mathrm{Mg}$ & $\mathrm{Si}$ & $\mathrm{Mn}$ & $\mathrm{Al}$ \\
\hline 1 & $2.20 \pm 0.4$ & - & $0.35 \pm 0.05$ & 98.65 \\
2 & $2.00 \pm 0.3$ & $<0.1$ & $0.41 \pm 0.05$ & 98.53 \\
3 & $0.19 \pm 0.03$ & $0.91 \pm 0.07$ & - & 98.78 \\
\hline
\end{tabular}




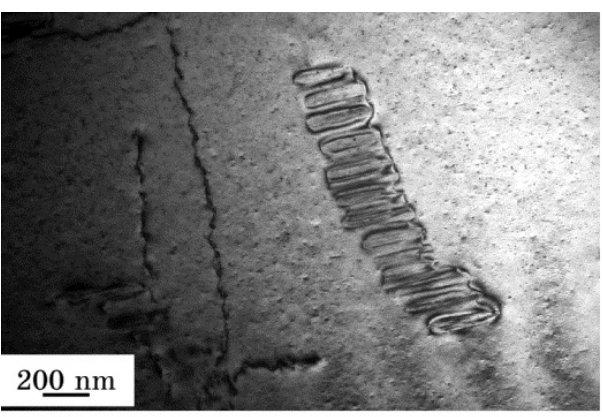

$a$

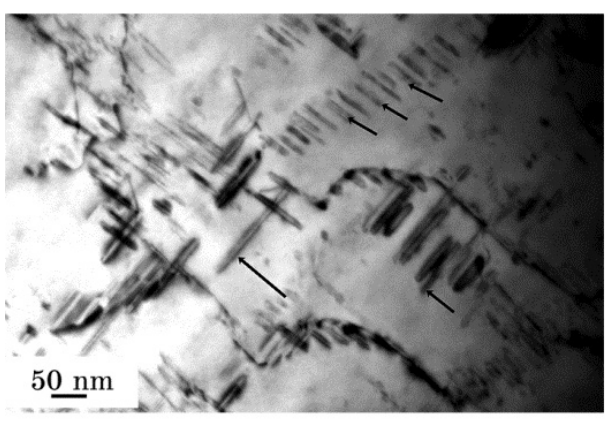

$c$

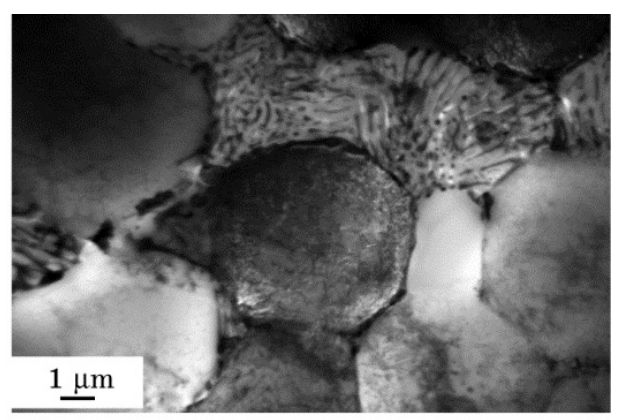

$b$

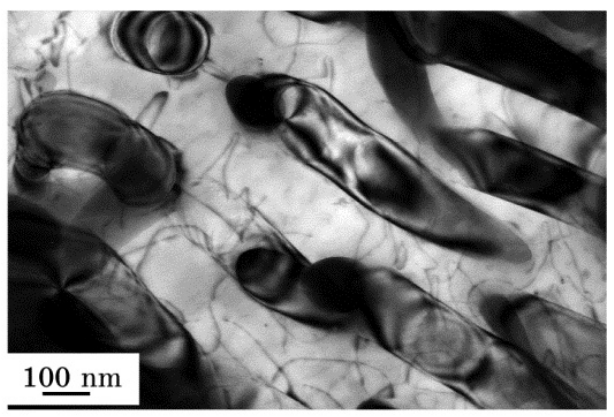

$d$

Fig. 5. Precipitates observed in samples $1(a)$ and 2 , their morphology $(a, c)$ and distribution $(b, d)$. Bright field image of precipitates in sample 1 aligned along a dislocation $(a)$. Bright field image of solid solution grains surrounded by $(\mathrm{Al})+\left(\mathrm{Mg}_{2} \mathrm{Si}\right)$ eutectic in sample $2(b)$. Bright field image of precipitates in sample 2 (marked by arrows). Precipitates are aligned along dislocations $(c)$. Bright field image of the interlamellar area in sample 2. No precipitates are observed $(d)$.

showed enrichment by $\mathrm{Mg}$ and $\mathrm{Si}$. The TEM investigation of sample 1 performed three hours after casting showed that there are no precipitates inside the $\alpha$-Al grains. The precipitates appear in samples examined after 3 days of exposure. Their growth sometimes could be observed directly in the microscope column, when the TEM foil is heated up by inelastic scattering. In summary, the TEM investigation gives:

- for both samples 1 and 2, precipitates are aligned along dislocations and show a similar morphology;

- precipitation density is much higher in sample 2 than in 1 ;

- precipitates are distributed only in the solid solution area, not among eutectic lamellas;

- precipitates are not formed earlier than two days after casting;

- precipitates contain mostly $\mathrm{Mg}$ and $\mathrm{Si}$.

From these observations together with the alignment of precipitates 
along dislocations, it can be concluded that the main mechanism of their formation is heterogeneous nucleation on dislocations during natural aging of the alloys.

\section{DISCUSSION}

Temperatures of endothermic processes detected in specimens 1 and 3 are in good agreement with those identified from equilibrium $\mathrm{Al}-\mathrm{Mg}-$ $\mathrm{Si}[8]$ and Al-Si [9] phase diagrams. Recent DSC studies performed by Petkov et al. [4] gave eutectic melting point for the commercial $\mathrm{AlMg} 5 \mathrm{Si} 2 \mathrm{Mn}$ alloy of $595.92^{\circ} \mathrm{C}$ and a peak temperature of $607.1^{\circ} \mathrm{C}$, which is in good agreement with temperatures detected by our DSC measurements of samples 1 and 2 .

Age hardening of $\mathrm{Al}-\mathrm{Si}-\mathrm{Mg}$ alloys is a sequence of precipitations, namely, GP-zone formation, $\beta^{\prime \prime}$ and/or $\beta^{\prime}$ transitional phases. The exothermic peak at $220-260^{\circ} \mathrm{C}$ found in our sample 3 DSC plots corresponds to the precipitation of coherent $\beta^{\prime \prime}$ phase in agreement with what was found by Wang et al. [6]. Such precipitation can take place in an alloy even by slightly elevated temperatures in as-cast condition, i.e. without preliminary solution treatment and quenching.

Comparing the heating behaviour of sample 1 and 2 , it can be concluded that the thermal history of the sample does not play an essential role for the reaction temperature. However, for both samples, there was no low-temperature effect as in sample 3 (see Fig. 2,c). This can be related to the different composition of the solid solution of the investigated samples (see Table 3). The $\alpha$-Al matrix of sample 3 contains 0.19 wt. $\% \mathrm{Mg}$ and 0.91 wt. $\% \mathrm{Si}$, which is enough to supply a density of $\beta^{\prime \prime}$ phase, which is high enough to be detected by DSC. In contrast, even for the HPDC sample 2 , the average $\mathrm{Mg}$ content in solid solution is about 2.1 wt. $\%$, but the Si concentration is below 0.1 wt. $\%$. Thus, the precipitates density for samples 1 and 2 will be much lower and the heat effect is of below the limit of detection.

The TEM observations clearly show that plate-like precipitates are present in sample 1 and 2 in as-cast condition. These particles are found in the $\alpha$-Al grains in the centre and close to the eutectic as well. They are formed without any heat treatment. From their alignment along dislocations, it is most likely that they form via heterogeneous nucleation, and that dislocations provide nucleation sites for their growth. Heterogeneous nucleation of precipitates in $\mathrm{Al}-\mathrm{Mg}_{2} \mathrm{Si}$ alloys on dislocations is a well-established mechanism during the decomposition of the solid solution. However, in most cases, this effect is considered for wrought alloys undergoing artificial aging. For casting alloys in cast condition, however, the direct formation of such a type of precipitates is not established yet.

The observation that high dislocation density is connected with a 
high density of precipitates supports our presumption that the nucleation of precipitates takes place on dislocations. In sample 2 , the density of dislocations is much higher and the precipitation density is larger than that for sample 1. Probably, the reason for the dislocations is thermal stresses between $\alpha-\mathrm{Al}$ and $\mathrm{Mg}_{2} \mathrm{Si}$ intermetallics and extrusion stresses during the HPDC process. When no pressure is applied during mould filling and solidification (sample 1), the precipitates density is much lower. Therefore, obviously, pressure plays a more important role for dislocation generation than thermal stress.

Ravi and Wolverton [10] found that for Mg-rich alloys the formation of $\mathrm{Mg}_{5} \mathrm{Si}_{6}$ is more favourable energetically. In our alloys, we found that areas with precipitates show enrichment with $\mathrm{Mg}$ and $\mathrm{Si}$. Therefore, it is most likely that these precipitates are $\beta^{\prime \prime}$-phase.

The strengthening role of precipitates formed via natural ageing can be simply verified by the results of hardness and microhardness measurements. The highest hardness $H B=95$ and microhardness $H V_{0.05}=$ $=96 \mathrm{kgf} \cdot \mathrm{mm}^{-2}$ was measured for sample 2 , where the precipitation density is much higher than that for sample 1 . The lowest hardness $H B=$ $=73$ and $H V_{0.05}=69 \mathrm{kgf} \cdot \mathrm{mm}^{-2}$ were found for sample 2 , where the precipitate density is lower than in sample 1 .

Similar precipitates are observed in as-cast condition of different casting alloys. Precipitates formed after one week natural aging in the $(\mathrm{Al}-\mathrm{Cu})$ casting alloy A201 cast into permanent mould. Additional research showed similar precipitation behaviour of the $\mathrm{Al}-\mathrm{Mg}-\mathrm{Si}-\mathrm{Mn}$ casting alloys after additional alloying with $\mathrm{Sc}+\mathrm{Zr}, \mathrm{Li}, \mathrm{Ti}+\mathrm{Zr}$. This could be a starting point for the development of Li-containing casting alloys, where simultaneously density is decreased and strength is improved by precipitation hardening.

\section{CONCLUSIONS}

The results of study of melting behaviour, microstructure and precipitation in the AlMg5Si2Mn alloy can be summarized as follows:

1. Both samples of AlMg5Si2Mn alloy produced via PM and HPDC route show similar behaviour on heating. Eutectic melting temperature is found of $596.2^{\circ} \mathrm{C}$, what is about $20^{\circ} \mathrm{C}$ higher than that of PM A356 alloy. The latter shows an exothermic effect at low-temperature part of DSC trace, thus confirming that the decomposition of solid solution may start directly from as-cast state. This low-temperature precipitation reaction is not observed for $\mathrm{AlMg} 5 \mathrm{Si} 2 \mathrm{Mn}$ alloy.

2. Phase morphologies are different for PM and HPDC AlMg5Si2Mn alloys. In PM casting alloy, where cooling rate is about $2 \mathrm{~K} \cdot \mathrm{s}^{-1}, \alpha-\mathrm{Al}$ grains are dendritic with well-developed branches, whereas HPDC alloy (cooling rate of $60 \mathrm{~K} \cdot \mathrm{s}^{-1}$ ) exhibits rosette-like grains with the size one order of magnitude lower than PM alloy. 
3. High mechanical properties of HPDC AlMg5Si2Mn alloy are related to the precipitation of plate-like precipitates, which are heterogeneously nucleated on dislocations. These precipitates are most obviously $\beta^{\prime \prime}$-phase, randomly distributed inside of solid solution grains. Density of precipitates is related to the density of dislocations. Larger precipitation density is found in HPDC alloy, and they are formed due to applied pressure on metal during solidification.

\section{ACKNOWLEDGEMENT}

Thanks are due to Prof. Dr. W. Reimers for his comments and suggestions, Eng. M. Hill for valuable help in metallographic specimen preparation. V. Boyko gratefully acknowledges the German Academic Exchange Service (DAAD) for financial support. Authors wish to thank 'Aluminium Rheinfelden GmbH' (Germany) for supplying the highpressure die-cast sample.

\section{REFERENCES}

1. M. C. Wuth, H. Koch, and A. J. Franke, Casting Plant and Technology International, 16: 12 (2000).

2. U. Hielscher, H. Sternau, H. Koch, and A. J. Franke, Light Metals 1996 (Ed. W. Hale) (TMS: 1996), p. 933.

3. S. Otarwanna et al., Met. Mater. Trans. A, 40A: 1645 (2009).

4. T. Petkov et al., BHM Berg- und Huttenmannische Monatsheft, 158, Iss. 3: 1 (2013).

5. G. K. Sigworth, H. Koch, and P. Krug, 40th Annual Conference of Metallurgists and Electrometallurgy. Light Metals Symposium (August 26-29, 2001, Toronto), p. 349.

6. G. Wang, L. Yan, G. Ren, and Z. Zhao, J. Mater. Eng. Performance, 20: 399 (2011).

7. Q. G. Wang and C. J. Davidson, J. Mat. Sci., 36: 739 (2001).

8. O. M. Barabash, O. V. Sulzhenko, T. N. Legkaya, and N. P. Korzhova, J. Phase Equilibria, 22: 5 (2001).

9. L. F. Mondolfo, Aluminum Alloys: Structure and Properties (London-Boston: Butterworths: 1976), p. 678.

10. C. Ravi and C. Wolverton, Acta Mater., 52: 4213 (2004). 